\title{
An Analysis on Dropout Levels of Public Secondary Schools in Kericho District in Relation to Selected School Characteristics
}

\author{
Anthony K. A. Sang ${ }^{1}$, Peter K. A. Koros ${ }^{1} \&$ Joseph N. Bosire ${ }^{1}$ \\ ${ }^{1}$ Faculty of Education, Egerton University, EgertonUniversity, Kenya \\ Correspondence: Anthony K. A. Sang, Faculty of Education, Egerton University, P. O. Box 536, \\ EgertonUniversity, Kenya. E-mail: korossp@yahoo.com
}

Received: April 24, 2013 Accepted: May 9, 2013 Online Published: July 1, 2013

doi:10.5539/ies.v6n7p247 URL: http://dx.doi.org/10.5539/ies.v6n7p247

\begin{abstract}
The Education Sector in Kenya and other parts of the world has faced many challenges particularly dropouts, which is an indicator of low internal efficiency during the past two decades. This study sought to determine and analyze the dropout levels of Public Secondary Schools in Kericho District of Kenya for the period between 2004 and 2007. The internal efficiency indicator that was examined in relation to school characteristics was dropout rates. Data was collected from Heads of schools and Guidance and Counseling Teachers in all the 64 public secondary schools in the district that were already doing KCSE examinations by 2004. The study employed Cross Sectional Research Design as a framework for data collection. Primary data on dropout levels was obtained from the respondents using structured questionnaire. Means, Percentages, Frequencies, Standard Deviations and T-tests were used to establish internal efficiency levels. Tests of significance were set at 5\% significance level. Statistical analysis was done using Statistical Package for Social Sciences (SPSS). The study revealed that dropout levels were higher in Day compared to Boarding schools, Mixed compared to Single Sex schools and Single Stream compared to more than one stream schools. The study also found that dropout rates increased with increasing levels of education. The findings of the study are expected to benefit the school managers especially the Board of Governors (BOG), the Parents Teachers Association (PTA) and Schools Principals, as well as the Ministry of Education in making decisions about school size, school regime and school type, with respect to internal efficiency indicators specifically dropout rates.
\end{abstract}

Keywords: dropout, school characteristics, school regime, school type and school size

\section{Background to the Study}

Internal efficiency indicators especially dropout rates in secondary schools is an emerging issue in Kenya and most countries of the world today. This is because a large amount of resources in terms of time, money and other supportive materials are often committed to the provision of secondary school education. Secondary school education in Kenya and most countries of the world usually start at fourteen years of age and runs for four years. Upon completion of secondary school, students can choose to go to college or pursue other vocational fields. Students who do well in secondary school are admitted to college, and others join teacher training institutions, technical training schools, or the job market. The competition for admission to colleges and Training Institutes is normally very high. The secondary school education programme is geared towards meeting the needs of both the students who terminate their education after secondary school and those who proceed to higher education (Republic of Kenya, 2003).

On student dropout, a study by Eisenmon (1997) reported that this phenomenon was prevalent in schools with ill-developed infrastructure and for the largest proportion of schools; it was the highest in form two classes where most students experienced multiple problems associated with adolescence and peer influence. A study by Lockheed \& and Verpoor (1991) on school principalship indicated a situation where over $70 \%$ of the primary schools under study had principals as males. The study concluded that a large number of administrative positions were male dominated in most institutions due to gender insensitivity in appointment to such positions.

The public and private demand for formal education system in Kenya is the highest in the country both in terms of the resources devoted to it and the proportion of Kenyans involved (Republic of Kenya, 2003). Despite the high demand for formal education in Kenya, the transition rate from primary to secondary cycle is low. A survey which was conducted by the Ministry of Education, Science and Technology (2003) revealed a trend which 
indicated that less than $60 \%$ of the pupils leaving primary schools have access to secondary education and the trend in recent years shows a decline to less than 50\% (MOEST, 2006). In 1999, Kenya achieved a Gross Enrolment Rate of $88.6 \%$ in primary education and $76.5 \%$ in secondary education. However, over the years this rate declined to $84.1 \%$ and $72.5 \%$ in 2003 for primary and secondary education respectively (MOEST/UNICEF, 2003). Latest reports indicate that this rate has dropped for secondary education to about $68.9 \%$ (MOEST/UNICEF, 2006). From this percentage on GER in secondary education, Day schools accounted for $42 \%$ while Boarding schools contributed the rest. The national rates tend to mask regional disparities, which show some districts, especially in the arid areas, recording participation rates below $30 \%$ with correspondingly high dropout rates.

In 2001, the national average for dropout rates was $7.8 \%$ and from this percentage there was $2.2 \%$ and $6.6 \%$ for boys and girls respectively. Against this, the main urban centres were better off with an average dropout rate of 4.3\%. The incidence of dropping out or non-enrolment has been on the rise attributably to a large extent to the Structural Adjustment Programme (SAP) which eroded the economic capacity of most families, thus rendering them unable to meet the education costs of their children (MOEST, 2003). The enrolment in the entire Formal Education Programmes according to ROK (2007) is about eight million which is about a quarter of the total population where secondary education constitutes a consolidation and transition between primary education and higher education and training and the world of work. The four years of secondary education are an important stage of physical, intellectual and psychological development when the youth matures into adult roles. As much as this is the situation, only $47 \%$ of those who complete primary education proceed to the secondary education while only $12 \%$ of this group proceeds for further education in public Universities and middle level colleges. From the $12 \%$ that proceed to the university, $4 \%$ are girls while $8 \%$ are boys. This is an indication that wastages exist in all levels of education system in Kenya and therefore there is need to carry out research and possibly influence policy formulation in an attempt to curb dropout levels in secondary education.

The secondary school cycle in Kenya faces internal efficiency challenges such as low transition rates between primary and secondary schools as well as high dropout rates. At both the primary and secondary schools, low internal efficiency levels is experienced as evidenced by high dropout rates and low progression rates (ROK, 2003). According to this report, School Size which refers to a school being either single stream or more than one stream, School Regime where a school is either boarding or day and School Type where a school is single sex or coeducational largely affect dropout and progression rates. Furthermore, it is noted that some of the causes of primary and secondary schools dropout include early marriages, inability to pay school fees due to poverty, hazards of HIV/AIDS pandemic, violence and drug-abuse (Achoka, 2007; ROK, 2003).

Gatawa (1998) notes that while developing countries have done remarkably well in terms of expanding educational access to an appreciably large percentage of their school going population, school performance as measured by dropout rates, progression rates and examination results has been quite discouraging. This view is shared by Bray, Clarke and Stephens (2002) who argue that no African country is nearing universal secondary education despite concerted efforts and heavy investments to do so. They also argue that quantitative differences are reinforced by the tendency of children to dropout at each stage and this is noted to be high in developing countries especially among the poor and among girls. The trend is shown in Table 1.

Table 1. Comparative Dropout rates from primary grade 1 after six years in selected African countries

\begin{tabular}{llll}
\hline Country & Percentage & Country & Percentage \\
\hline Benin & 39.9 & Madagascar & 75.4 \\
Botswana & 16.5 & Mali & 50.6 \\
Burundi & 55.1 & Niger & 40.3 \\
Chad & 71.5 & Rwanda & 66.8 \\
Congo & 29.2 & Senegal & 34.0 \\
Cameroon & 42.5 & Sudan & 25.0 \\
Gabon & 49.6 & Swaziland & 31.0 \\
Gambia & 4.9 & Tanzania & 14.6 \\
Ghana & 28.2 & Zaire & 59.4 \\
Ivory coast & 19.8 & Zambia & 21.8 \\
Kenya & 22.3 & & \\
Lesotho & 53.0 & & \\
\hline
\end{tabular}

Source: Adopted from Bray, Clarke and Stephens (2002:76) 
Table 1 shows that dropout, which is one of the factors that affect the internal efficiency in schools, exists in African countries with the highest percentage recorded in Madagascar (75.4\%) while the lowest is in Gambia (4.9\%). This shows that dropout of whatever magnitude exist in a number of countries of the world especially in the continent of Africa (Bray et al, 2002).

In 2002, the overall drop-out rate in Kenyan Secondary schools was $6 \%$ for males and $17.9 \%$ for females. The access rate to Universities in Kenya was 7\%. This was because of many challenges ranging from limited space in the Universities, financial limitations, early marriages to low aspirations (MOEST, 2002). In the Kenya Education Sector Support Programme (2005-2010) which is a publication of the Ministry of Education, the government outlines the policy framework to make education more accessible to all. The programme notes that wastage arising from dropout is a serious challenge that must be addressed so as to ensure that resources in terms of time, energy, money and opportunity cost are not wasted. The declining participation rates and wastage that result from dropping out are issues of concern to the government and every effort is being made to address them. To cushion the poor against the effects of SAP, the Government of Kenya has launched the Social Dimension of the Development Programme whose aim is to assist communities and families to participate in income generating activities that could raise their earning levels. Table 2 shows this trend in enrolment and corresponding wastage from dropouts in secondary education.

Table 2. Enrolment and Dropout in Secondary Education in Kenya 2002 and 2003

\begin{tabular}{llllllll}
\hline Year & $\begin{array}{l}\text { No. of sec. } \\
\text { schools }\end{array}$ & Enrolment & Total & Dropouts and percentages & Total \\
\hline & & Males & Females & & Females & Males \\
2002 & 2834 & 336437 & 283400 & 619839 & $50802(17.9 \%)$ & $20405(6 \%)$ & 71207 \\
2003 & 2878 & 341807 & 290581 & 632388 & $51613(17.8 \%)$ & $20922(6.1 \%)$ & 72535 \\
Total & 5712 & 678244 & 573981 & 1252227 & 102415 & 41327 & 143742 \\
\hline
\end{tabular}

Source: Adopted from the MOEST 2002:12

In the manual for Head Teachers, which is a publication of the Kericho Head Teachers Association (2007), Kericho District had a Dropout rate of $28.6 \%$ and completion rate of approximately $62 \%$ for most schools. On Dropout rate, girls contributed $18.4 \%$ and boys $10.2 \%$ respectively. Pass rate which is the ability of students to attain atleast grade $\mathrm{C}$ in $\mathrm{KCSE}$ which, is the minimum requirement for admission into tertiary institutions for further training lies at $37 \%$ on average for most secondary schools (MOEST, 2003). The trend for dropout in Kericho District for the years 2004-2006 is shown in Table 3.

Table 3. Enrolment and Dropout rates in Secondary Education in Kericho District in 2004-2006

\begin{tabular}{llllll}
\hline Year & $\begin{array}{l}\text { No. } \\
\text { schools }\end{array}$ & of & Enrolment & Dropout \\
& & Males & Females & Males & Females \\
2004 & 64 & 11,675 & 7,525 & 3,339 & 2,152 \\
2005 & 67 & 12,428 & 7,672 & 3,554 & 2,194 \\
2006 & 71 & 15,885 & 8,965 & 4,543 & 2,564 \\
Total & 202 & 39,988 & 24,162 & 11,436 & 6,910 \\
\hline
\end{tabular}

Source: Adopted from the MOEST 2006:121

It is therefore necessary for Kenya and other countries of the world to investigate why this trend exists and if possible come up with measures to minimize its levels and deal with causes. Bray et al (2002) assert that high dropout rate which is high among the low income groups and girls is another threat to issues of internal efficiency of the school system. Pupils who drop out from school complicate enrolment forecasts, teacher supply forecasts and erode the education budget. 


\subsection{Objective of the Study}

The study was guided by the following objective:

(i) To determine the dropout levels in public secondary schools in Kericho District by School Characteristics for the years 2004-2007.

\subsection{Hypotheses of the Study}

$\mathrm{HO}_{1}$ : There is no statistically significant difference in the levels of dropout between public secondary schools of different School Regimes in Kericho District for the years 2004-2007.

$\mathrm{HO}_{2}$ : There is no statistically significant difference in the dropout levels between Public secondary schools of different School Types in Kericho District for the years 2004 -2007.

$\mathrm{HO}_{3}$ : There is no statistically significant difference in the levels of dropout between public secondary schools of different School Sizes in Kericho District for the years 2004-2007.

\subsection{Limitations of the Study}

This study relied on school records to be able to analyze and determine dropout rates. The study also focused on few selected School Characteristics and therefore findings have to be generalized with caution to schools with similar characteristics. The study involved eighty respondents. The target was 128 respondents drawn from Principals and Guidance and Counselling teachers. Some of the respondents remained reluctant to respond to some items while others did not return their questionnaires. This may have affected the findings of the study with regard to specific items and information that would have been useful from the non-responses. However, the study still solicited information on dropout from the schools where principals were reluctant to give responses through the help of the Guidance and Counselling teachers. Statistical data were collected for years gone by and some documents like student registers were difficult to access. However, efforts were made to try to generate data from the available school documents. In addition, the location and sample size required generalization with caution where conditions of learning are different in the rest of the country and outside. These have acted as limitations to the study.

\section{Literature Review}

Education is one of the basic services offered by governments and other stakeholders to society. Authors including Bray (1996) and Miller (2001) posit that education is a tool for economic development and therefore there is need to constantly review inputs and outputs in the system. If education is to meet the goal of economic development in any nation, then aspects of internal efficiency should be examined critically. The term "efficiency" as applied in education refers to the extent to which education yields desirable results to the society and individuals (Ayodo, Gatimu \& Gravenir, 1991).

A study that was carried out by the Association for the Development of Education in Africa (2006), indicated that there were a number of obstacles to high level achievement of internal efficiency in schools. It was noted that delays in the acquisition of inputs to a large degree affected internal efficiency. For instance, even after the resources were made available, some schools would still take two to three months to avail to the students. Of concern also was the increased student numbers leading to shortages of teachers. This problem according to the study was further enhanced by the fact that governments have been replacing only those teachers who die, resign or retire. The ability of most governments to maintain positive trends in education is held back in particular by severe budgetary constraints.

\subsection{Student Dropout Levels and School Characteristics}

Eisenmon (1997) in a study on wastages in secondary education reported that dropout rates in developing countries often are quite high. Besides, the study found that Boarding Schools were preferred by most stakeholders since students did better than their day schools counterparts in national examinations. Notably conspicuous in this study was that dropout rates were higher in Day schools compared to Boarding schools. According to this study, the highest rates were in the sub-Saharan African countries where each year, about 22 percent of primary schools pupils and 21 percent of secondary schools students were dropping out of school. Out of the total percentage of dropouts in secondary education, Boarding schools accounted for 8 percent while Day schools accounted for 13 percent. The North African and Middle Eastern countries averaged about 12 percent for the primary grades and 21 percent for the secondary grades.

From these percentages, Single Streamed schools accounted for 7 percent while 14 percent came from schools with two streams or more. This was because the Single Stream schools were fewer than the Double or More Streamed schools and the study established that most education stakeholders preferred Large Size schools on the 
grounds of the economies of large-scale production. The Latin American and Caribbean countries averaged 9 percent and 8 percent for primary and secondary schools respectively. The data from East and South-East Asia were too sporadic to support meaningful averages, but the available number appeared comparable to those for Latin America.

According to EFA (2009), Kenya has the largest percentage of her children in both primary and secondary school of which 13 percent drop out of school at any given time due to poverty, early marriages, HIV/AIDS pandemic and poor learning environment. Sessional paper No. 1 (2005) on Education, Training and Research indicates a transition rate of $70 \%$ from primary to secondary education cycle and this is an indication that approximately $30 \%$ of the pupils nationally are unable to proceed to secondary schools. A study on rural day schools by Ncube (2004) in Zimbwabwe found that the number of students dropping from a level increased with the level of schooling.

\section{Research Methodology}

This study used cross sectional research design, which is a type of survey design normally used in situations where the population of study is large and is examined at a single point in time (Borland, 2001). Cross sectional research design involves collection of data on more than one case at a single point in time in order to gather a body of quantifiable data in connection with two or more variables, which are then examined to detect their pattern of association (Bryman, 2004). This study did not develop new treatments but examined the effects of naturally existing treatments after the occurrence of the treatments. The study examined the aspects of student dropout in public secondary schools for the years 2004-2007, which have already occurred. The design therefore made it possible for the determination of the effects of occurring independent variable, which is school characteristics on the dependent variable namely: dropout rates.

\section{Results and Discussions}

Findings from the study are presented using frequencies, percentages, means, standard deviations and T-test. The levels of internal efficiency specifically dropout levels according to School Characteristics are presented and discussed. Statistical tests were done using Statistical Package for Social Sciences (SPSS) for windows version 11.5. The study sought to determine the levels of dropout in public secondary schools in relation to selected School Characteristics for the years 2004-2007. The mean dropout rates for various class levels in relation to the selected school characteristics for this period are examined. The significance level of difference in dropout in relation to selected School Characteristics is also examined by testing hypotheses.

\subsection{Dropout rates (2004-2007)}

Information on dropout rates from the respondents was analysed against school characteristics and by class levels. The mean dropout rate was generated according to class levels and school characteristics. Table 4 shows the mean dropout rates according school regime characteristics.

Table 4. Mean dropout rates by School Regime

\begin{tabular}{|c|c|c|c|c|c|c|}
\hline $\begin{array}{l}\text { Category } \\
\text { schools }\end{array}$ & of & Variable of dropout & Form one & Form two & Form three & Form four \\
\hline \multirow[t]{2}{*}{ Boarding } & & Mean & 1.36 & 1.74 & 1.29 & 1.18 \\
\hline & & Standard deviation & 0.346 & 0.426 & 0.535 & 0.32 \\
\hline \multirow[t]{2}{*}{ Day } & & Mean & 1.39 & 1.61 & 1.35 & 1.36 \\
\hline & & Standard deviation & 0.294 & 0.497 & 0.475 & 0.261 \\
\hline
\end{tabular}

Source: Field data, 2010

Generally, the mean dropout rate in all classes is higher in Day schools compared to Boarding schools, except for form two. In both Day and Boarding schools, the mean dropout is higher in form two compared to other classes (see table 4). The high mean dropout rate recorded in form two, as this study established was attributed to adolescence, which is at the peak for most students at this level of education. For this reason, most students may drop from school due to premarital pregnancies, peer influence, indiscipline and early marriages. These results are consistent with those of Kainja \& Mkandawire (1989) who found that as students experience multiple dropouts, girls are more disadvantaged because the issues of adolescence bring about competing demands in the 
school, the home and in the community with the associated ills of pregnancy and early marriage. The high dropout in day schools as compared to boarding schools as this study found is largely due to the external environment in which day scholars are faced with on daily basis as they commute to and fro school. These findings are similar to those of Ncube (2004) who in his study on Rural Day schools in Zimbabwe, found that the highest recorded dropout was due the influence of the home and the school surrounding environment.

A further analysis was done to establish which category of schools had the highest mean dropout rate. The results of this analysis are shown in Table 5

Table 5. Mean Dropout by School Regime

\begin{tabular}{lccll}
\hline School Regime & N & Mean & Std. Deviation & Std. Error Mean \\
\hline Boarding Schools & 25 & 1.39 & .38593 & .06822 \\
Day Schools & 34 & 1.43 & .36096 & .05210 \\
\hline
\end{tabular}

Source: Field Data

The results in Table 5 show that the mean dropout rate was higher in Day schools (1.43\%) than Boarding schools $(1.39 \%)$ in Kericho District. Though the mean dropout difference was by a small margin, there is evidence that the highest number of students who drop out of secondary school cycle before completion come from the Day category of schools.

Based on the differences in the means for the two categories of schools, there was need to establish if these differences in the means were statistically significant. In order to establish whether the difference in the mean dropout rates between the Day and Boarding schools were statistically significant, a t-test for equality of means was computed at $5 \%$ significance level. The null hypothesis tested was:

$H_{0}$ : There is no statistically significant difference in the mean dropout rates between Boarding and Day schools for the years 2004-2007.

The T-test model used to test this hypothesis is:

$\mathrm{H}_{0}: \mu_{1}=\mu_{2}$

where $\mu_{1}$ and $\mu_{2}$ represent the mean dropout rates in Boarding and Day schools respectively.

Table 6 gives a summary of the t-test results.

Table 6. T-test on Mean Dropout Rates by School Regime

Levene's Test for t-test for Equality of Means

Equality of Variances

\begin{tabular}{|c|c|c|c|c|c|c|c|}
\hline & F & Sig. & $\mathrm{t}$ & $\mathrm{df}$ & $\begin{array}{l}\text { Sig. } \\
\text { (2-tailed) }\end{array}$ & $\begin{array}{l}\text { Mean } \\
\text { Difference }\end{array}$ & $\begin{array}{l}\text { Std. Error } \\
\text { Difference }\end{array}$ \\
\hline $\begin{array}{l}\text { Equal variances } \\
\text { assumed }\end{array}$ & .002 & .969 & .123 & 57 & .902 & .0104 & .08469 \\
\hline $\begin{array}{l}\text { Equal variances } \\
\text { not assumed }\end{array}$ & & & .121 & 63.464 & 904 & .0104 & .08584 \\
\hline
\end{tabular}

t-critical $(\mathrm{df}=2,57, \mathrm{t}=1.96, \mathrm{p} \leq 0.05) ; \mathrm{t}$-calculated $(\mathrm{df}=2,57, \mathrm{t}=0.123, \mathrm{p}=0.902)$

Results in Table 6 indicate that there is no significant difference in the mean dropout rates between the Boarding and Day category of schools $(\mathrm{t}=0.123, \mathrm{p}=0.902>0.05, \mathrm{df}=2,57)$. This is further shown where the critical value of $t(1.96)$ is greater than the calculated value (0.123). Therefore, the null hypothesis $\left(\mathrm{H}_{0}\right)$ is accepted. This may imply that the differences in the dropout rates for the two categories of schools were small and that in most cases 
dropout levels may have been the same. Since the difference in dropout rates for the two categories of schools is small, same policies on how to minimize dropout levels could be generated for schools in Kericho District and other parts of the country with similar conditions.

This finding contradicts other studies that have shown that student dropout levels in Day schools are significantly high compared to Boarding schools. A study by Ncube (2004) on rural Day schools in Zimbabwe found that the rate at which students dropped from day schools due to challenges associated with Day schools in the rural setting was quite high to the extent that parents sought government intervention to convert a good cross-section of Day schools to Boarding schools. This was because dropout levels in Boarding schools in Zimbabwe was relatively low while retention and completion rates in the same schools were quite high.

\subsection{School Type Mean Dropout}

Another characteristic that was analysed against the mean dropout rates was the School Type. Here, the mean dropout rates for the years 2004-2007 was analysed based on whether a school was Single Sex or Mixed. The study sought to establish and compare the mean dropout rates for the two categories of schools. This was done by coding and keying in all the responses from the eighty respondents drawn from the sixty-four secondary schools in Kericho District. Once all the responses had been keyed in, a cross tabulation between the category of schools and the mean dropout rates was done. The mean of means was also generated to establish which of the two categories in overall had the highest recorded mean dropout rates.

Table 7 shows the mean dropout rates under the School Type categorization and by class levels.

Table 7. Mean Dropout Rates by School Type and Class levels

\begin{tabular}{|c|c|c|c|c|c|}
\hline $\begin{array}{l}\text { Category of } \\
\text { Schools }\end{array}$ & Variable of dropout & Form one & Form two & Form three & $\begin{array}{l}\text { Form } \\
\text { four }\end{array}$ \\
\hline \multirow[t]{2}{*}{ Single Sex } & Mean & 1.23 & 1.54 & 1.25 & 1.15 \\
\hline & Standard deviation & 0.23 & 0.48 & 0.44 & 0.36 \\
\hline \multirow[t]{2}{*}{ Mixed } & Mean & 1.65 & 1.86 & 1.37 & 1.21 \\
\hline & Standard deviation & 0.49 & 0.51 & 0.54 & 0.33 \\
\hline
\end{tabular}

Source: Field Data, 2010

From the results in Table 7, it is observed that the mean dropout rates in all classes is generally higher in Mixed schools compared to Single Sex schools except in form four. There is also an indication that the mean dropout rates are generally higher in lower forms for both categories of schools. The highest recorded dropout was in form two for both categories of schools. These findings are similar to those of UNICEF (2002) which found that dropout in schools was higher in rural schools where boys and girls attended the same classes and lower in those where girls attended classes separate from those of boys. Other students as the study found, in the Mixed schools especially girls' schools dropped from school at this level due to premarital pregnancies while boys left school to take up family responsibilities. These results are also consistent with those of Kainja \& Mkandawire (1989) who found that girls dropped from school mainly in form two due to premarital pregnancies and especially in Mixed schools.

The study, based on the mean dropout differences, further sought to establish and determine which of the two categories of schools had the highest contribution in terms of the overall mean dropout rates for all classes. This was done by calculating the mean of means for each category of schools and the results of this analysis are shown in Table 8.

Table 8. Mean Dropout by School Type

\begin{tabular}{lllll}
\hline School Type & $\mathrm{N}$ & Mean & Std. Deviation & Std. Error Mean \\
\hline Single Sex & 43 & 1.3178 & .33743 & .04393 \\
Mixed & 21 & 1.5714 & .39641 & .08650 \\
\hline
\end{tabular}

Source: Field Data, 2010 
Generally, the observation made from data in Table 8, shows that Mixed secondary schools have a higher dropout rate $(1.57 \%)$ compared to the Single Sex counterpart with $1.31 \%$. This seems to suggest that in Kericho District, the largest bulk of those students who dropped from school during the years 2004-2007 came from Mixed secondary schools. The factors that were identified as contributing to this high dropout rate in Mixed secondary schools included negative community influence, low entry behaviour of students and premarital pregnancies since both sexes of students learnt in the same environment. The findings of this study are consistent with other studies which show that Mixed schools has a higher contribution to the number of students dropping out of school compared to Single Sex schools. A study on student dropout in secondary schools by Mensch and Lloyd (1997) in urban schools found that the highest recorded number of students who frequently dropped from schools for various reasons came the Mixed category of schools.

In view of the evidence that mean differences in dropout rates existed between Mixed and Single Sex schools in Kericho District, a t-test for equality of means was used to test if statistically significant differences existed in the mean dropout rates for the categories of schools. In order to be able to do this, a hypothesis was postulated and tested. The hypothesis tested was:

$H_{0}$ : There is no statistically significant difference in the mean dropout rates between $\quad$ Single $\quad$ Sex $\quad$ and Mixed secondary schools in Kericho District for the years 2004-2007.

The t-test model used to test this hypothesis is:

$\mathrm{H}_{0}: \mu_{1}=\mu_{2}$

where $\mu_{1}$ and $\mu_{2}$ were the mean dropout rates in Single Sex and Mixed schools respectively.

Table 9 shows the results of this analysis.

Table 9. T-test on Mean Dropout Rate by School Type

Levene's Test for t-test for Equality of Means

Equality of Variances

\begin{tabular}{llllllll}
\hline & $\mathrm{F}$ & Sig. & $\mathrm{t}$ & $\mathrm{df}$ & $\begin{array}{l}\text { Sig. } \\
(2 \text {-tailed })\end{array}$ & Mean Difference & $\begin{array}{l}\text { Std. } \\
\text { Difference }\end{array}$ \\
$\begin{array}{l}\text { Equal variances } \\
\text { assumed }\end{array}$ & .001 & .982 & -2.824 & 62 & .006 & -.2536 & .08982 \\
$\begin{array}{l}\text { Equal variances } \\
\text { not assumed }\end{array}$ & & & -2.614 & 30.936 & .014 & -.2536 & .09702 \\
\hline
\end{tabular}

$\mathrm{t}$-critical $(\mathrm{df}=2,62, \mathrm{t}=1.96, \mathrm{p} \leq 0.05) ; \mathrm{t}$-calculated $(\mathrm{df}=2,62, \mathrm{t}=-2.824, \mathrm{p}=0.006)$

Results in Table 9 indicate a situation where the calculated value of $\mathrm{t}(-2.824)$ is less than the critical value (1.96). In addition, $\mathrm{p}=0.006<0.05$; the results show that the $\mathrm{t}$-value is significant at $\mathrm{p}<0.05$. Consequently, the null hypothesis is rejected and therefore there is a statistically significant difference in the dropout rates between Single Sex Schools and Mixed Schools. These results may serve to show that the variation in dropout levels in Mixed Secondary Schools are significantly different from those of the Single Sex Secondary Schools. This scenario may also generate the view that the factors responsible for student dropouts in schools are different for the Mixed and Single Sex schools.

Few studies that have been done on School Type and Internal Efficiency largely concur with the findings of the current study. A study on Internal Efficiency in Kenyan primary schools by Abagi \& Obwocha (2001) found that low internal efficiency arising from dropout was particularly higher in Mixed schools compared to Single Sex schools. The study cited poverty, negative community influence and premarital pregnancies in Mixed schools as responsible for the largest percentage of student dropout. However, the study pointed out that the effect of these factors was least felt in Single Sex schools since this category of schools were mainly Boarding schools, which were sealed off from community's external influence. 


\subsection{Mean Dropout Rates by School Size}

The mean responses from various respondents were analysed and compared in terms of whether a school was Single Stream or More than One Stream (School Size). Here, each category of schools was put together and their mean dropout rates compared.

Table 10 shows the results on mean dropout rates according to this categorization and by class levels.

Table 10. Mean Dropout Rates by School Size

\begin{tabular}{|c|c|c|c|c|c|}
\hline $\begin{array}{l}\text { Category of } \\
\text { schools }\end{array}$ & Variable of dropout & Form one & Form two & Form three & Form four \\
\hline \multirow[t]{2}{*}{ Single stream } & Mean & 1.09 & 1.81 & 1.41 & 1.36 \\
\hline & Standard deviation & 0.59 & 0.63 & 0.64 & 0.60 \\
\hline \multirow{2}{*}{$\begin{array}{l}\text { More than One } \\
\text { Stream }\end{array}$} & Mean & 1.19 & 1.53 & 1.22 & 1.19 \\
\hline & Standard deviation & 0.35 & 0.50 & 0.38 & 0.28 \\
\hline
\end{tabular}

Source: Field data, 2010

The results in Table 10 show that the mean dropout rate was generally higher in Single Stream schools compared to More than One Stream schools for all classes except form one. The study also established that most Single Stream schools in the District were young upcoming schools that took students who had scored low in their primary school examination. The students in such schools kept looking for vacancies in well established schools and when they finally succeeded, left the Single Stream schools. The largest number of students who dropped from the Single Stream schools was due to transfers. There is also an indication from the findings in Table 10 that for both categories of schools, this rate was generally higher in form two compared to other classes. The reasons that the respondents cited as causing the high dropout rate in Single Stream schools included transfer to other schools since most of such schools had ill-developed infrastructure including libraries and science laboratories. The study also established that the high dropout in form two was due to peer influence, premarital pregnancies and poor academic performance.

These results contradict the general beliefs that Single Stream schools are easily managed, do well in examinations and have high retention rates (ROK, 2003). These findings are consistent with those of Eisenmon (1997) who found that dropout in most schools is generally higher in form two compared to other classes and that ill-developed infrastructure was identified as a factor in rural Single Stream schools that largely contributed to students' dropout through transfer to better-equipped schools.

The study, based on the mean dropout differences that existed between the Single Stream and More than One Stream schools, further sought to establish and determine which of the two categories of schools had the highest contribution in terms of the overall mean dropout rates for all classes. This was done by calculating the mean of means for each category of schools and the results of this analysis are shown in Table 11.

Table 11. Mean Dropout by School Size

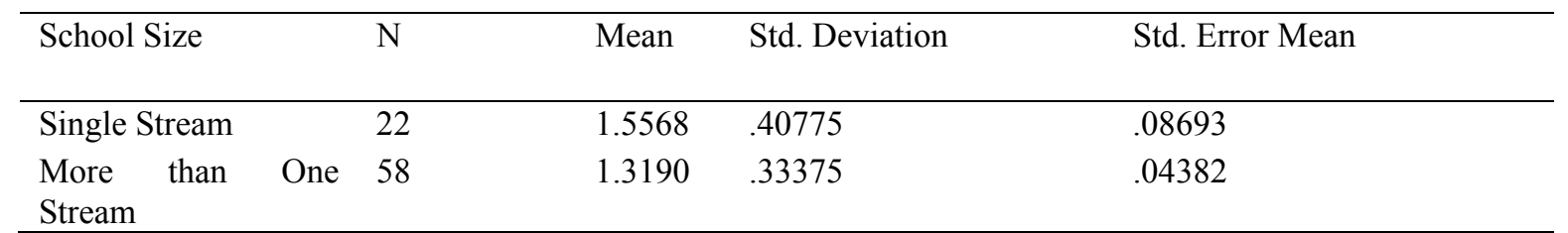

Source: Field Data, 2010

There is a general observation from the data in Table 11 that the Single Stream category of schools had a higher mean dropout compared to the Large Sized group of schools. As cited earlier (see Table 11), the main cause of dropout in the Single Stream schools was transfers by students to schools which were perceived to be better equipped in terms of human and physical facilities. Other studies by Koros (2006) and Scharff and Brady (2006) also contend that improving school facilities in most cases reduces cases of student dropout arising from 
transfers to better equipped schools. A more recent study by Jagero et al (2009) cited poor infrastructure in Boarding schools as responsible for student dropout since parents preferred having their children in schools with good facilities.

In the light of the evident mean dropout differences, there was need to establish if the means for the Single and More than One Stream schools were significantly different. In order to be able to do this, a t-test for equality of means was computed and a hypothesis was postulated and tested. The null hypothesis tested was:

$H_{0}$ : There is no statistically significant difference in the mean dropout rates between Single Stream and More than One Stream secondary schoolsin Kericho District for the years 2004-2007.

The t-test model used to test this hypothesis is:

$\mathrm{H}_{0}: \mu_{1}=\mu_{2}$

where $\mu_{1}$ and $\mu_{2}$ were the mean dropout rates in Single Stream and More than One Stream schools respectively.

Table 12 shows the t-test results of the null hypothesis.

Table 12. T-test on Mean Dropout Rate by School Size

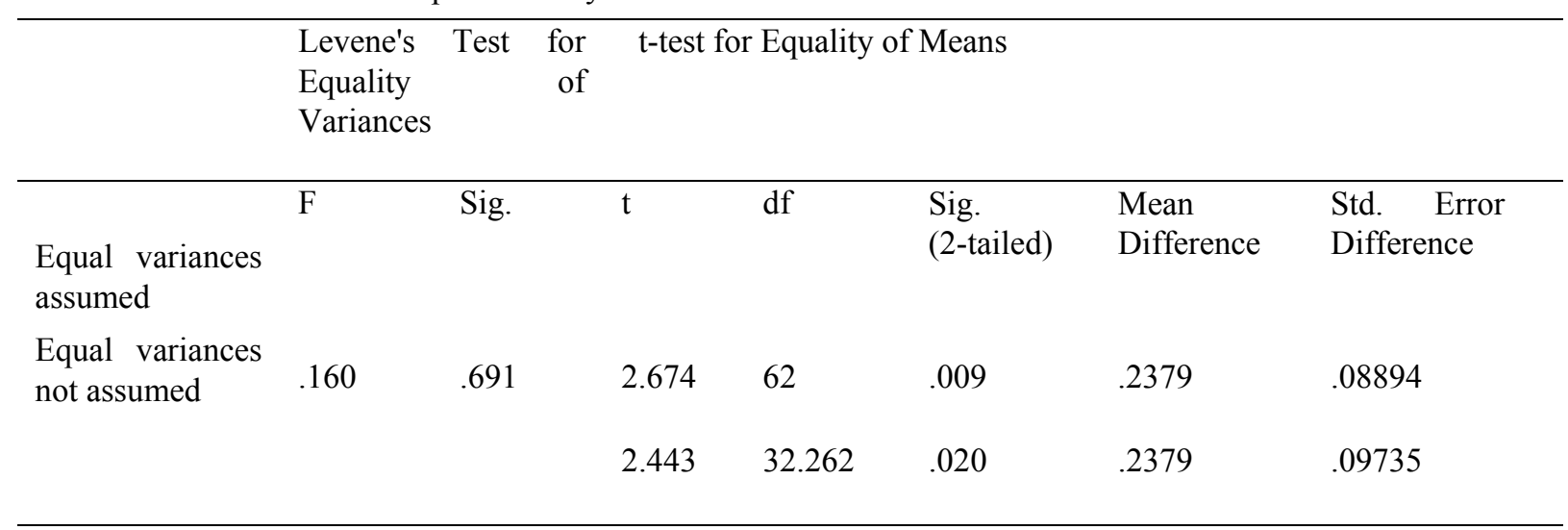

t-critical $(\mathrm{df}=2,62, \mathrm{t}=1.96, \mathrm{p} \leq 0.05) ; \mathrm{t}$-calculated $(\mathrm{df}=2,62, \mathrm{t}=-2.674, \mathrm{p}=0.009)$

Results in Table 12 shows that the calculated t-value (2.674) is greater than the critical value of $t$ (1.96). In addition, the p-value of 0.009 is less than 0.05 and this shows that the mean difference in dropout rates for Single Stream and More than One Stream schools is statistically significant. From this observation, the null hypothesis is rejected. These results may serve to show that the differences that exist in dropout levels between Single Stream and More than One Stream schools are significantly different and that factors attributed to this situation in both categories of schools may be uniquely different. These results are consistent with those IIEP (2001) which in a study on internal efficiency of urban schools found that the variation in dropout levels that existed between Single Stream and More than One Stream was not quite high. The study in the light of the findings recommended separate intervention measures for the two categories of schools in as far as student dropout is concerned.

\section{Summary of Findings}

The study found that school characteristics contributed to differences in dropout rates in schools and that dropout rates decreased with increasing levels of schooling. The study also established that generally the mean dropout rate in classes was higher in day schools compared to boarding schools except in form two. The mean dropout rate was highest in form two classes for both single sex and mixed schools though mixed schools generally recorded a higher mean dropout rate.

\subsection{Conclusions}

From the responses of the principals and counselling teachers on dropout rates by class levels, there is an indication that the highest dropout was recorded in form two for a good proportion of schools in the district and therefore if measures on curbing school dropout are to be formulated and implemented, form two classes should be targeted. The implication as the study found is that at this level of education, peer influence and adolescence is at the peak for most students and therefore students should be helped along these lines so they are retained in school to course completion. This study concluded that most schools have not put in place measures to deal with 
dropout in form two which recorded the highest dropout rate and therefore there is need to step up guidance and counselling as a measure to curb this rate can be curbed (see table 4).

\subsection{Recommendations}

Dropout rates in schools were found to be higher in Day schools compared to Boarding schools (Table 9) though there was no significant difference in the dropout rates between the two categories of schools. However, day schools are more vulnerable to dropout than Boarding schools due to high prevalence of negative community influence, peer influence, premarital pregnancies and early marriages in day schools. This study recommends a policy that will see all day schools converted to boarding schools so as curb the factors attributed to student dropout in this category of schools.

It was observed from the study that the mean dropout rate was generally higher in Mixed schools compared to Single Sex schools except in form four. There is need to investigate why this rate is higher in mixed schools and the Ministry of Education and other stakeholders should look for measures to harness this rate so that student progression in this category of schools is enhanced. There is need to step up guidance and counseling units in Mixed schools so that those who would have dropped out of schools due to premarital pregnancies and peer influence are helped to stay on in school to course completion. This study recommends that the community around the school should be sensitized against cultural practices that are retrogressive to student progression.

The study also established that the mean dropout rate was generally higher in single stream schools than more than one stream schools for all classes except form one. There is also an indication that for both categories of schools, this rate was generally higher in form two compared to other classes (Table 12). Based on these findings, this study recommends that infrastructure which was cited as the main cause of student dropout in the Single Stream schools should be improved. The MOEST should assist the Single Stream schools to construct libraries and science laboratories so as to boost academic performance and thereby lowering dropout rates.

Progression rates in all categories of schools were higher in Boarding schools compared to Day schools, Single Sex compared to Mixed and More than One Stream compared to Single Stream schools. Based on these findings, this study recommends that the MOEST put in place measures to increase progression levels in the day, mixed and single stream secondary schools.

From the responses of the principals and counselling teachers on dropout rates by class levels, there is an indication that the highest dropout was recorded in form two for a good proportion of schools in the district and therefore if measures on curbing school dropout are to be formulated and implemented, form two classes should be targeted. The implication as the study found is that at this level of education, peer influence and adolescence is at the peak for most students and therefore students should be helped along these lines so they are retained in school to course completion. This study concluded that most schools have not put in place measures to deal with dropout in form two which recorded the highest dropout rate and therefore there is need to step up Guidance and Counselling as a measure to curb this rate can be curbed.

\section{References}

Abagi, O., \& Obwocha, W. (2000). "Household Based Factors as determinants of School Efficiency in Kenya. Research Report, Nairobi: AAS

Abagi, O., \& Obwocha,W. (2001). 'The Impact of politicized Education reforms on quality of Secondary Education: Experience from Kenya'. In Watson $\mathrm{K}$ et al Educational dilemmas: Debate and diversity. London: CASSEL

ADEA. (2001). Teacher Resource Centres; Baseline study on cluster centres. Paris: Commonwealth Secretariat.

ADEA. (2003). "The challenge of learning: Improving the quality of Basic Education in Sub-sahara Africa." ADEA discussion paper, in ADEA Biennial meeting, Grand Baie, Mauritius.

ADEA. (2003). Ministry of Education country case study: Impact of Primary Education Reform Programme on the Basic Education, Uganda.

Afonso A., \& Aubyn M. (2005). "Cross-country efficiency of Secondary Education Provision: A semi-parametric Analysis with non-discretionary inputs", Working Paper series, No. 494, available at: http:/scrn.com/abstract-id $=726688$.

Alexander, L., \& Simons, J. (1995). The Determinants of School Achievement in Developing countries: The educational Production Function. World Bank Staff Working Paper no. 221 Washington, D.C.

Ayodo, T. M. C., Gatimu K., \& Gravenir (1991). Economics of Education. Nairobi: University of Nairobi Press. 
Bayne-Jardine, C., \& Wood, M. (2000). Improving quality in Education. London: Falmer Press.

Borg, W. R., \& Gall, M. D. (1995) Educational Research. New York: Longman

Borland, K. W. (2001). Qualitative and Quantitative Research: A complementary balance. New directions for Institutional Research. http://dx.doi.org/10.1002/ir.25

Bray M., Clarke P. B., \& Stephens, D. (2002). Education and Society in Africa, London: Edward Arnold.

Bryman. (2004) Social Research Methods, second edition New York: Oxford University Press.

Chiuri, W., \& Kiumi. (2005) Planning and Economics of Education. Nairobi. Pangolin Publishers.

Eisenmon, T. (1997). Reducing Repetition: Issues and strategies. Paris: IIEP-UNESCO

Gatawa, B. S. M. (1998). Quality- Quantity Dilemma in Education: The Zimbabwe experience. Harare: College Press

GOK. (1996). Sessional Paper no.2 on Industrial transformation to the year 2020. Nairobi Government printer.

GOK. (1998). Social Dimensions of Development: Revised Approach to Human Centred Development and targeted poverty interventions. Nairobi: Government printer.

GOK. (1999). Commission of Inquiry into the Education System in Kenya. Nairobi. Government printer.

GOK. (2004). Ministry of Education, Science and Technology; Report of the Task Force on Implementation of Free Primary Education: Nairobi Jomo Kenyatta Foundation.

GOK. (2005). Geographic Dimensions of Well-Being in Kenya: Where are the poor? From Districts to Locations., Vol. 1, Government Printer, Nairobi.

Grisay, A., \& Mahlck, L. (2001). The quality of Education in developing countries: A preview of some research studies and policy documents. Paris: IIEP

Haddad, \& Wadi. (1998). Educational and Economic effects of Promotion and Repetition practices. World Bank Staff Working paper no. 319. Washington, D.C.

Heneveld, W., \& Craig, S. (1994). Planning and Monitoring the quality of primary education in Sub- Sahara Africa. Washington, D.C., Human Resources and Poverty Division, School efficiency, African Region: World Bank.

Heyman, S., Jamison, T., Dean, T., \& Montenegro. (1998). Textbooks in the Philippines: Evaluation of pedagogical impact of a nationwide investment. Education, Evaluation and Policy Analysis. Baltimore: Hopkins University press.

IIEP. (1999). Internal Efficiency of Educational System. Paris: IIEP.

IIEP. (2001). School Supervision in Four Countries: Volume II: National Diagnoses. Paris: IIEP.

Kainji, K., \& Mkandawire, F. (1989). National case study on the role of female teachers in the enrolment and persistence of girls in primary schools in Malawi: Unesco, Malawi chapter. Bulawayo.

Kapasaka, A. M. (1992). Determination of Girls Participation and Persistence in schools in Malawi: World Bank Population adnHuman Resources Division; Southern African Department.

Kathuri, N. J., \& Pals, D. A. (1993). Introduction to Educational Research. Egerton University, Njoro, Kenya: Education Media Centre. Act press.

KDHA. (2007). A Handbook Manual for Head Teachers. A Publication of the heads Association, Kericho District. Amu Press.

Keller, Warrack, \& Bartel, H. (1994). Statistics. Carlifornia, Duxbury press.

KES (2006) A Survey on the Status of Education in Kenya: An examination on Dropout and promotion rates in the school system. Nairobi, Government printer.

Koros, K. A. P. (2006). Masters thesis on Stakeholders perceptions on parental contribution secondary school management in Kericho District. Egerton University.

Kyungu, S. (2000). A hand book manual for head teachers on Enrolment and wastages in Education. Nairobi.

Leedy, P. D. (1997) Practical Research. Planning and Designing, New York: Mcmillan.

Lockheed, C. (1993) Effective schools in Developing countries. London: The Falmer press. 
Meadows, K. A. (2003). So You Want To Do Research? 2: Developing Research Questions. British Journal of Community Nursing.

MOEST. (2002). Effectiveness and Efficiency in the Management of Schools. A Handbook for Head Teachers on the Management of Secondary Schools in Kericho District. A Publication of the Ministry of Education.

MOEST. (2003). An overview on Human Development through Education and Training: Policies and Programmes priorities: Nairobi, Government printer.

Mugenda, O. M., \& Mugenda, A. G. (1999). Research Methods. Qualitative and Quantitative Approaches. Nairobi. Act Press.

Ncube, N. J. (2004). Managing the quality of Education in Zimbabwe: The Internal Efficiency of Rural Day Schools. Unpublished Phd thesis. Harare, University of Zimbabwe.

Nitko, A. J. (1996). Educational Assessment of students. New Jersey: Merril.

Njeru, E., \& Orodho, J. A. (2003). Access and Participation in Secondary School Education in Kenya. Emerging Issues and Policy Implications, IPAR DP 037/2003, Regal Press Kenya Ltd, Nairobi.

Orodho, J. A. (2005). Statistics made User Friendly for Educational and Social Science Research. Masola Publisher.

Psacharopaulos, G., \& Woodhall, M. (1985). Education and Development: An Analysis of investment choices. New York: Oxford University Press.

Republic of Kenya. (2003). Educational sector Strategic plan and implementation practices: 2003-2007. Nairobi: Ministry of Education, Science and Technology. NBI: MOEST.

ROK. (1999). Totally Integrated Quality Education and Training. Nairobi: Government Printer.

Smith, P. J., \& Cronje, D. (1997). Management Principles. Cape Town: Juta and Company.

Steyn G. M. (1999). The implementation of Total Quality Management principles in an American School. Periodical for primary education: New York.

Tuckman B. W. (1994). Conducting Educational Research. New York: Harcourt Brace College.

UNESCO. (2005). Challenges of Implementing Free primary Education in Kenya. British Educational Research Journal, 30(3), 395-411.

UNICEF. (2002). A Review of evaluation of UNICEF Education activities (1994-2000). Paris: UNICEF

USAID. (2005). Ministry of Education, UPE Magazine: Enhancing Universal Primary Education, Nairobi.

Weller, L. D. (1995). School Restructuring and Downsizing: Using Total Quality Management to promote effectiveness. London: Longman.

Wheeler, D. (1995). Human Resource Development and Economic growth in Developing Countries: A simultaneous model. World Bank staff working paper, Washington, D.C.

\section{Copyrights}

Copyright for this article is retained by the author(s), with first publication rights granted to the journal.

This is an open-access article distributed under the terms and conditions of the Creative Commons Attribution license (http://creativecommons.org/licenses/by/3.0/). 